Purdue University

Purdue e-Pubs

Charleston Library Conference

\title{
Great Expectations: New Organizational Models for Overworked Liaisons Based on the UNCG Libraries Liaison Collections Responsibilities Task Force
}

\author{
Steve M. Cramer \\ University of North Carolina at Greensboro, smcramer@uncg.edu \\ Beth R. Bernhardt \\ University of North Carolina at Greensboro, beth_bernhardt@uncg.edu \\ Mike A. Crumpton \\ University of North Carolina at Greensboro, macrumpt@uncg.edu \\ Amy L. Harris \\ University of North Carolina at Greensboro, a_harri2@uncg.edu \\ Nancy B. Ryckman \\ University of North Carolina at Greensboro, nancy_ryckman@uncg.edu \\ Follow this and additional works at: https://docs.lib.purdue.edu/charleston \\ Part of the Library and Information Science Commons \\ An indexed, print copy of the Proceedings is also available for purchase at: \\ http://www.thepress.purdue.edu/series/charleston. \\ You may also be interested in the new series, Charleston Insights in Library, Archival, and Information \\ Sciences. Find out more at: http://www.thepress.purdue.edu/series/charleston-insights-library-archival- \\ and-information-sciences.
}

Steve M. Cramer, Beth R. Bernhardt, Mike A. Crumpton, Amy L. Harris, and Nancy B. Ryckman, "Great Expectations: New Organizational Models for Overworked Liaisons Based on the UNCG Libraries Liaison Collections Responsibilities Task Force" (2012). Proceedings of the Charleston Library Conference. http://dx.doi.org/10.5703/1288284315112

This document has been made available through Purdue e-Pubs, a service of the Purdue University Libraries. Please contact epubs@purdue.edu for additional information. 


\title{
Great Expectations: New Organizational Models for Overworked Liaisons Based on the UNCG Libraries Liaison Collections Responsibilities Task Force
}

\author{
Steve M. Cramer, Business Librarian, UNC Greensboro \\ Beth R. Bernhardt, Electronic Services Librarian, UNC Greensboro \\ Mike A. Crumpton, Assistant Dean for Administrative Services, UNC Greensboro \\ Amy L. Harris, Reference Librarian and Information Literacy Coordinator, UNC Greensboro \\ Nancy B. Ryckman, Reference and Instructional Services Department, UNC Greensboro
}

\begin{abstract}
Liaisons (subject specialists) keep getting busier. Research instruction, embedding in classes, outreach, collection development, weeding, assessing teaching and collections, promoting scholarly communication issues, and creating online learning objects are all potentially part of what a liaison is expected to do nowadays. So we hope every liaison is very interested-and very good-at all those responsibilities. Is that realistic? And does a liaison have time for all those things?

At University of North Caroline at Greensboro (UNCG), library administrators decided it is time to examine how liaisons are organized to manage all of these competing responsibilities. The library formed a Liaison Collection Responsibilities Task Force to benchmark how other libraries might be handling the complexities of liaison responsibilities in innovative ways and to recommend several possible new organizational models for the collection development and public services work of liaisons.

Members of the task force will review their benchmark findings and invite the audience to provide their own examples. Then we will present our recommendations for new organization models. Some recommendations will reflect incremental changes; others will be radical. We will ask the audience for feedback on the recommendations and suggestions for other models.
\end{abstract}

\section{Introduction}

The UNCG Libraries have a "liaisons do it all" approach, in which each liaison handles collection management, teaching, outreach, promotion of scholarly communication issues and options, etc., for his/her academic departments. So we hope every liaison is very interested-and very goodat all those activities.

But the list of activities only gets longer: the emphasis on scholarly communication, assessment of teaching, ROI analysis of collections spending, creating online research workshops for distance education classes, and embedding in every live learning community are all relatively new. As liaison responsibilities continue to grow, will a liaison have time to do it all and do it well? Is it realistic to expect such an exceptional skill set for each liaison?
In response to the ever-increasing workload of liaison work, the Dean of the UNCG Libraries created a task force to explore some possible solutions, beginning with collections work.

\section{Our Task Force Charge}

"The enhanced responsibilities of our liaisons have created some very real issues regarding the amount of time that can be spent on collection development. As new responsibilities emerge and the way in which we handle collection development has changed, it is time to examine how we are organized to manage all of these competing responsibilities. To that end, this task force is charged to:

1. Define the collection development, instruction, outreach, and newly defined and enhanced responsibilities of our liaisons. 
2. Define the ways that collection development has changed over the years.

3. Benchmark with other libraries to see how they are handling the complexities of liaison responsibilities in new, creative, and innovative ways.

4. Recommend an organizational model for collection development and other liaison responsibilities that will allow us to give the proper attention to both areas in a sleek and efficient way. More than one organizational model should be recommended providing alternatives to choose from.

The Task Force is encouraged to consult/talk with others in the Libraries and to consider focus group interactions with academic faculty members in order to provide more voices to the final report."

Updated Charge from UNCG Libraries

Administration after Its June 2012 Retreat

After some strategic planning, Library Administration told the task force members that they would like the liaisons to focus on public service work and spend much less time on collections.

\section{Major Responsibilities of Liaisons}

This is a summary of the most important possible responsibilities of liaisons. The actual work a liaison does will vary by his/her skill sets and the academic departments being served. (The issue of varying skill sets would be mitigated by the adoption of subject teams.)

\section{Teaching}

- Teach library and research instruction for classes, departments and other groups (ex. new graduate students) in classrooms and computer labs as well as online using distance education software.

- Work with professors on information literacy goals, instructional design and creating research assignments.
- Create and maintain class guides (ex. LibGuides) and Blackboard links to library resources.

- Create digital learning objects (ex. videos) to assist with instruction.

- Assess information literacy skills.

\section{Research Support and Consulting}

- Provide consultations to students and faculty. (Consultations usually last at least 15 minutes; may be held in library offices, group study spaces, or other campus buildings; and feature complex and/or multi-step research support or training).

- Provide subject-specific research and reference services in person and through email, phone, chat, DE software, etc.

- Provide support of citation management tools, current awareness tools, and others.

\section{Outreach and Promotion}

- Provide outreach to departments, schools, Learning Communities (LCs), student groups, and academic and service centers. (Outreach includes attending academic departmental meetings, new student orientation, and special events; creating promotional fliers, web content, or videos; introducing oneself to new faculty, students, and staff in person or via e-mail; etc.)

- Embed in classes and LCs.

- Participate in faculty and departmental events and monitor departmental, school, and student organization developments through social media.

- Create digital learning objects (ex. videos) to support outreach and promotion.

\section{Collections}

- Oversee development of print book collections and modifications of approval plans; coordinate the work of faculty liaisons in firm order budget selecting; select books as needed. 
- Evaluate parameters and options for patronselect e-books.

- Evaluate databases, e-book packages, and other resources for potential purchase or subscription; advocate for subscriptions funded through the XDBS, serials, and DE budgets.

- Evaluate subscriptions for possibly cancellations and weed physical collections to maintain the quality and support space planning goals.

- Share news of new and updated resources with faculty.

- Analyze usage data.

- Contribute to reaccreditation review reports, new academic program applications, and grant proposals.

\section{Scholarly Communication}

- Promote open access and other scholarly communication options to faculty.

- Promote submitting content to NC DOCKS and the publishing of electronic journals using Open Journal System software.

- Keep up with trends and developments and share them with faculty as needed.

\section{Professional/Skills Development}

- Maintain and develop skills in teaching, assessment, instructional technology, and outreach.

- Maintain and develop subject expertise and knowledge of subject-specific research tools

- Maintain training-level knowledge of generaluse scholarly tools like EndNote, Web of Science, etc.

\section{Strengths and Weaknesses of Our Current Liaison Organizational Model}

\section{Our Current Organizational Model}

- The Assistant Director for Collections and Technical Services (AD) supervises the
Collections and Scholarly Resources Coordinator (CSRD). The CSRD supervises one half-time employee who works on the institutional repository.

- The $A D$ and the CSRD regularly organize collections and liaisons meetings.

- There is no direct supervisory or evaluative authority over the liaisons for their liaisonspecific responsibilities.

- Liaisons are based in many departments. Each liaison is supervised and evaluated by his or her particular department head.

- Academic credentials, experience, personal interest, or organizational need usually determine which liaison is assigned to a specific academic department, to a student group, or to one of the many learning communities.

- Requests for materials may go to the liaison, the $A D$, the CSRD, or to Acquisitions.

- Requests for class instruction may go to the liaison or to the Literacy Instruction Coordinator based in the Reference and Instructional Services Department (RISD).

- The majority of the liaisons are in RISD which has occasional discussions about teaching, assessment, and other public service aspects of liaisons work. The Library Instruction Coordinator is based in RISD.

- The Distance Education Librarian (who is also a liaison) is based in ERIT.

- Partnerships between two or more librarians and/or staff members who will share liaison responsibilities are being explored.

\section{Strengths of the Current Model}

- Every academic department, many student groups, and some learning communities have a specific liaison assigned to them.

- Teaching faculty and students have the name of a single contact person they can rely on for assistance.

- Individual liaisons, working with the same departments or individuals over time, build 
rapport that may encourage more contact between the liaison and the faculty and students in that department or group.

- Liaisons are empowered to focus on the aspects of liaison work they most enjoy or for which they have the most expertise.

- Liaisons are empowered to make decisions and seek assistance from other liaisons without going through a supervisory structure.

\section{Weaknesses of the Current Model}

- There is no holistic supervisory or evaluative structure for either the liaison program or the individual liaisons.

- Liaisons are based in several library departments; therefore, each may be evaluated in a different way by the supervisor on that person's liaison responsibilities.

- There is no central, regular reporting of liaison activities (including success stories and innovations) or statistical data. We do not review service gaps for potential improvements for academic departments.

- There is no dedicated SPA or student worker support of liaison activities.

- We expect each liaison to be very skilled in all aspects of liaison work: teaching, assessment, outreach, collections, instructional technology, etc. That expectation is not realistic.

- Liaisons may be assigned to departments for which they have no subject expertise or personal interest, thus making it more difficult to offer substantive assistance to the assigned unit.

- There are considerable discrepancies in the amount of time liaisons devote to their specific departments, students, and other campus groups such as LCs. Students and faculty in some units may require extensive use of the liaison's time while other units require little time.

- While providing instruction is expected of every liaison, meetings on best practices for teaching tend to be limited to the liaisons in RISD.

- There is a "one size fits all" approach to liaison work with no provision for prioritizing which departments should get more attention and effort based upon the number of their constituents, their reliance on library resources, the need for research instruction, or the department's strategic importance to the university.

- As the campus adds more PhD programs, LCs, student groups, research centers, etc., and as library services and liaison responsibilities continue to grow, it becomes more difficult for the current liaisons to absorb the extra work (This challenge became even greater when the library lost a liaison position to Library Administration in 2009.). Our current liaison model is not sustainable.

\section{Benchmarking}

We benchmarked innovate organizational models through:

- Searching the Library Literature database;

- Browsing the library web sites of the UNC and peer campuses;

- Searching library web sites; and

- Asking around at summer conferences.

We couldn't find any articles directly addressing innovative liaison models. Some articles discussed the changing roles of the subject specialist in collections work; a few discussed the results of liaison partnerships.

We did not find any evidence of innovative models at other UNC or peer campuses. However, we did find two examples through Google searches: Villanova and Johns Hopkins. Beth Filar Williams learned about an interesting decentralized model through a friend at Utah State. We contacted those three libraries to learn more about how their models work. We also discussed issues with liaison work with a group of Wake Forest librarians as well as the liaison coordinator at UNC Chapel Hill. 
Below, we present our key findings based on our surveys, and details on the Utah State, Villanova, and Johns Hopkins models.

\section{Our Key Findings:}

1. Most academic libraries have a decentralized liaison organizational model like ours.

2. Most libraries-unlike ours-have a collections department. The smallest such departments have a department head and several staff members; larger ones include a mix of staff and library faculty (some of these departments have positions that roughly correspond to positions we have in Acquisitions and Electronic Resources \& Information Technology.).

3. Some libraries have co-liaisons or liaison partners, with staff, library faculty, or LIS interns working with the original liaison. A few libraries have liaison teams, for example, the "Humanities Team."

4. Only a few libraries have centralized departmental models for liaison work. Johns Hopkins and Villanova are examples.

5. Some large research libraries have formally prioritized the responsibilities of liaisonsmaking engagement, not collections, the top priority. This trend seems to have begun with Minnesota. Duke, Kansas, and Washington are following Minnesota's example.

\section{Utah State}

Summary: Decentralized subject teams with functional coordinators. The liaisons continue to be based in several traditional library departments. The task force feels this is an admirable and holistic approach for organizing decentralized liaisons, but still perpetuates the weaknesses of a decentralized model.

This narrated PowerPoint describes the new model succinctly:

Flora G. Shrode, Jennifer R. Duncan, and Wendy Holliday. "An Entrepreneurial Approach to Librarianship" ACRL/LLAMA Spring Virtual Institute. Apr. 2010. http://works.bepress. com/jennifer_duncan/21
Abstract: Librarians from Utah State University explain recent efforts to encourage subject librarians to take a more holistic view of their roles. We are shifting from a traditional emphasis primarily on collection development and refocusing on natural connections between collections, instruction, liaison, and reference service. The poster provides background about Utah State University's situation and explains our approach to analyzing local needs and culture to inform development of a new organizational structure. We describe our vision of subject librarianship, the process by which we assessed librarians' ideas and goals for performing as subject librarians, and the actions we are taking to accomplish our goals.

The involvement of the four coordinators (Head of Reference, Head of Collections, Coordinator for Regional Campuses \& Distance Education, and Coordinator of Library Instruction) in the work of the subject teams emphasizes the core responsibilities of liaisons at Utah State.

All the subject librarians meet monthly; the four coordinators plan the agenda. The subject teams only meet a few times a year. (In addition, the liaisons have their normal departmental meetings; for example, the liaisons in Reference Services attend Reference meetings.)

The Subject Librarian Advisory Committee (SLAC) replaced their former Collection Development Advisory Council to better reflect the many responsibilities of liaisons. SLAC discusses major policy questions. Patron-driven interlibrary loan acquisition and a redesign of the e-resource access pages are examples of projects covered by this group. SLAC meets quarterly.

From an e-mail exchange, we learned that Utah State is happy with their new model (including their increased role in collections). However, they report that "some uncertainly remains...from the fact that subject librarians report to many different departments so it's not always clear who evaluates performance in collection development and related roles." 


\section{Villanova}

Summary: An "Academic Integration" department that covers instruction, research consulting, collection development, and LibGuides through seven liaison teams (http://library.villanova.edu/ about/departments/academicintegration/liaisonte ams/), a department head, functional coordinators, and support staff.

This department was once a traditional reference department; there was also one collection development officer. References services are now covered by the interdepartmental Information and Research Assistance Team. Some members of the Academic Integration department serve on that team.

Most of the subject teams have three or four members. Each team has a coordinator. Most academic departments at Villanova still have an identified liaison, as seen in their LibGuides.

The functional coordinators work with the department coordinator to set the goals of the department, plan meetings and workshops, and assist each subject team as needed.
According to department coordinator Jutta Seibert, "each liaison team establishes their own work priorities according to expertise and talents available among team members. Liaison teams are accountable for their activities in their individual annual report and in team activities reports." She added that the revisioned department is working well and that "overall we had much positive feedback from faculty for this new model."

The technical specialists assist the librarians and the subject team with any projects that need support. The department coordinator listed for us the major responsibilities of these two staff positions:

- Scheduling the research support calendar;

- Supervising and training student workers;

- Collecting usage statistics for journals;

- Collecting and entering instruction statistics;

- Collecting Web statistics via Google Analytics;

- Manipulating research support statistics;

- Assisting with marketing initiatives;

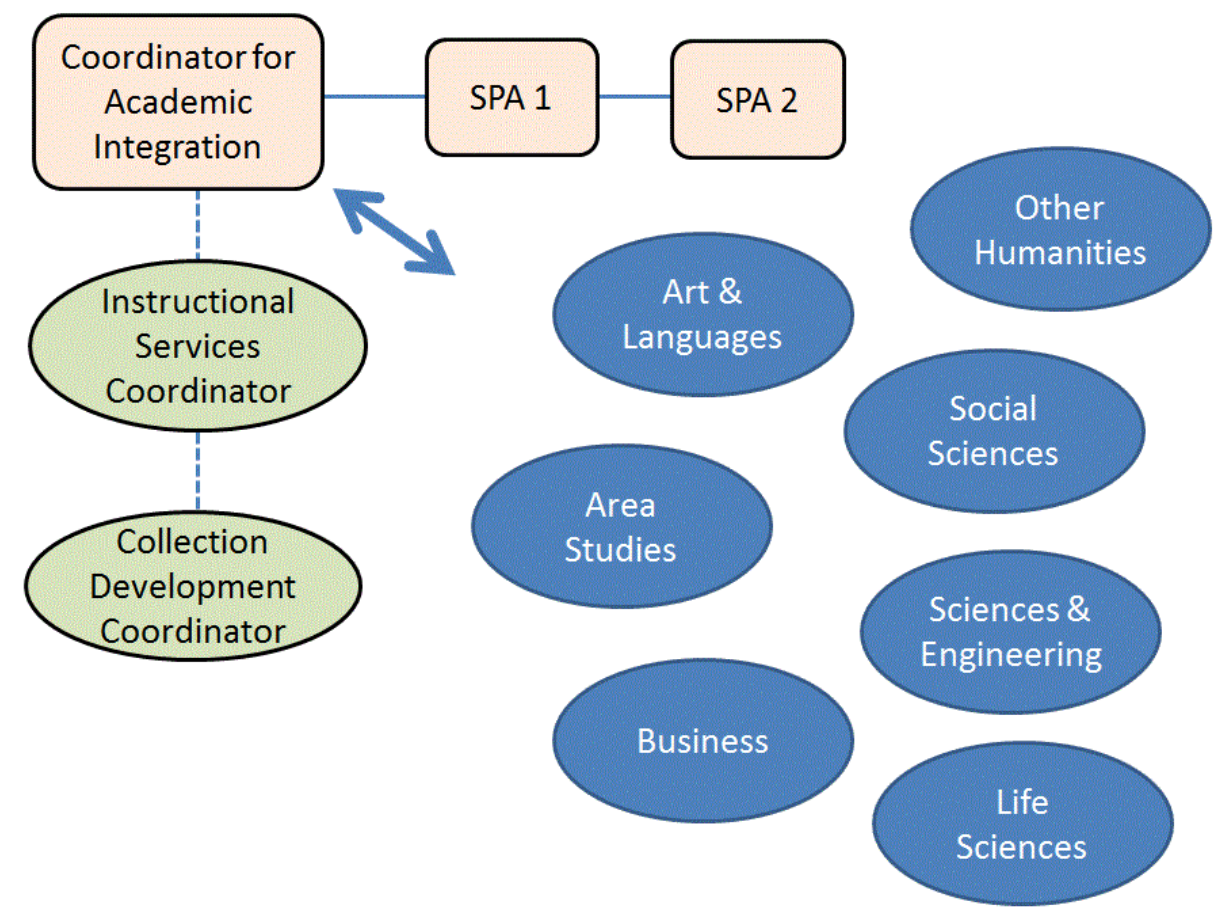

Figure 1. The Villanova Academic Integration Department 
- Assisting with a large variety of collection development projects from checking holdings in the catalog to pulling books from the shelves; assisting with the evaluation of donations to working on circulation statistics and spreadsheet projects;

- Assisting with events such as new faculty orientation, parents fair, etc.;

- Archiving documentation on a shared drive; and

- A small amount of clerical work such as typing address labels and handling print and photocopying jobs.

The library has two press releases about the creation of the department:

- Director's Watch column: Recent developments here at Falvey (2006) http://newsletter.library.villanova.edu/story. php?id=122

- Focus on Falvey's new organizational structure: Academic Integration (2007) http://newsletter.library.villanova.edu/170

Johns Hopkins

Summary: An "Academic Liaisons" department that covers collections, reference services and research consultations, and instruction. Unlike at
Villanova, Johns Hopkins does not have subject teams. Like Villanova, the functional coordinators work with department head Margaret Burri (who is also an Associate Dean) on leadership and performance evaluations. (This department used to be the Research Services Department. Many but not all of the liaisons still have reference desk hours, however.)

Oddly, not all of the liaisons are based in this department. Most of the other liaisons are based in the Scholarly Resources and Special Collections (SRSC) Department. However, the SRSC Associate Dean has a close working relationship with the Academic Liaisons (AL) Associate Dean and invites the AL Dean to help write annual evaluations of the SRSC-based liaisons.

The AL department has a monthly meeting on library instruction and a monthly meeting on research support. At the encouragement of the SRSC Dean, most of the liaisons in SRSC participate in those meetings and find them valuable.

The AL department is working on reducing the collections development work load of the liaisons in order to allow the liaisons to focus on public services.

Despite the absence of formal subject teams, the AL Dean told us that "Liaisons are generally

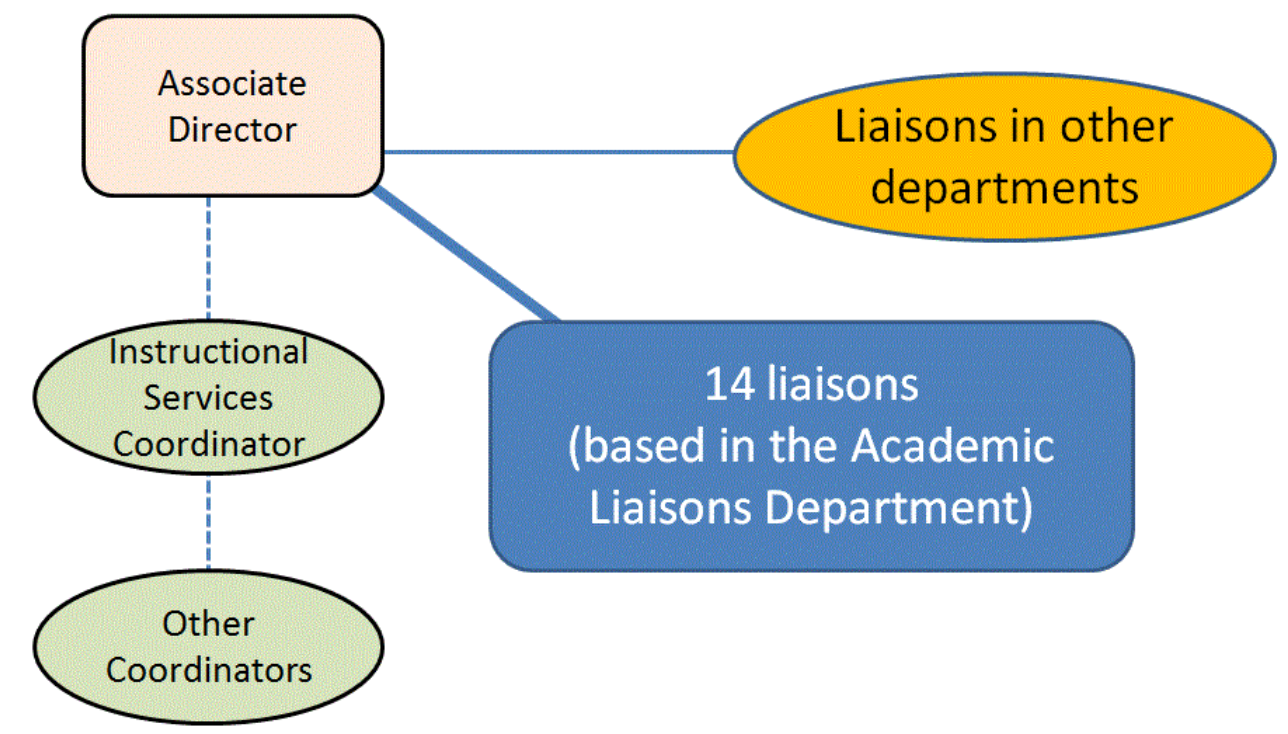

Figure 2. The Johns Hopkins Academic Liaisons Department 
allowed to focus on their strengths/what they do best. The library assumes that liaisons will be the most productive with their favorite kind(s) of liaison work. Liaisons really into instruction usually end up helping with instruction in other academic departments beyond their official liaison areas; likewise liaisons really into collections work. The department does try to evaluate workload and the effectiveness of the core liaison responsibilities, and makes changes to responsibilities in response (an ongoing effort)."

Some peer-assessment is done, for example, with peer review of teaching (the teaching librarian gets to choose who the peer reviewer is each year). The peer reviews do not become part of the official annual review.

There are no staff positions in the AL department. "It would be nice to have some," the Dean reports.

The library also has interdepartmental functional teams based on interest and skills. The Assessment Team is one example.

\section{Recommended Organizational Models}

1. Collections Department Model

2.Subject Team Model of a Liaisons Department

\section{Functional Team Model of an Academic Integration Department}

\section{Collections Department Model}

If liaisons will be expected to spend much less time with collections work, then much of that workload will have to be handled elsewhere. A Collections Department-even if small-could relieve the liaisons of that workload. Since most academic libraries have a collections department, we feel this is a conservative recommendation.

Our recommended model for a Collections Department is simple: the Collections Coordinator focuses on collections work and supervises at least one SPA worker who supervises a student worker. The Coordinator reports to the Assistant Dean for Collections and Technical Services.

Currently the Collections and Scholarly Resources Coordinator position is split between three broad responsibilities: collections, scholarly communication, and History Department liaisoning. We would like to see this position be focused on collections work, with perhaps the Assistant Dean for Collections and Technical Services assuming leadership of scholarly communication. In many libraries, the scholarly communication and collections are coordinated by two separate positions, reflecting the

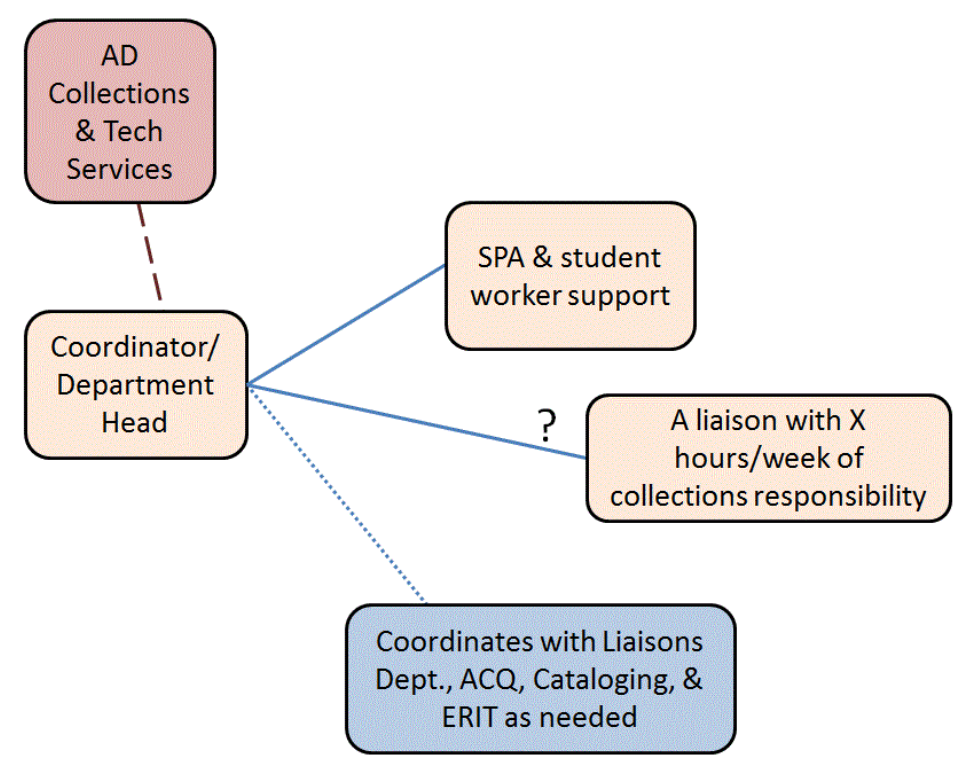

Figure 3. A Proposed Collections Department 
importance, significant workload, and distinctive skill sets of each area.

If the Collections Coordinator also has a liaison role, that role should be limited to academic departments deemed to receive only limited liaison support. (Below, we address the role of "full time liaisons" - those in the proposed liaison department, whose focus as liaisons is on engagement-compared to the "part-time liaisons" - those whose main responsibility is not liaison work (eg. the current liaisons in ERIT) and do not have time to focus on time-consuming engagement activities.)The proposed SPA position assists the coordinator with routine collections work and special projects. Examples include:

- Developing spreadsheets related to budgets, subscriptions, collections, etc.;

- Collecting usage statistics and preparing reports on that data;

- Checking holdings in catalogs;

- Assisting with title-by-title book selection and maintenance of the approval plan;

- Working on weeding projects;

- Assisting with promotional initiatives;

- Evaluating donations;

- Communicating with faculty, liaisons, and vendors; and
- Supervising and training student workers.

For example, much of the so-called "spreadsheet busy work" could be handled by this SPA position. Liaisons would only need to get involved when big decisions need to be made.

Academic departments that primarily receive collections support (not public service support) from the library could perhaps be served by the Collections coordinator and SPA position, instead of the current "part-time" liaisons.

It may be useful for the Collections Department to include a liaison who divides his or her time between the Collections and Liaisons Departments. This liaison could be one with strong interest and skills in collections work who can help both departments with the shift of collections work from one department to the other.

To facilitate the transfer of most collections work from liaisons to this department, perhaps the liaisons should begin keeping track of collections projects they are currently doing. We could review this list in terms of what work needs to be assumed by the Collections Department and what work can be scaled back or dropped completely. We should also consider services (e.g., adding more patron-driven acquisitions aggregators and expanding the approval plan) that might reduce collections workload, and what policies (e.g.,

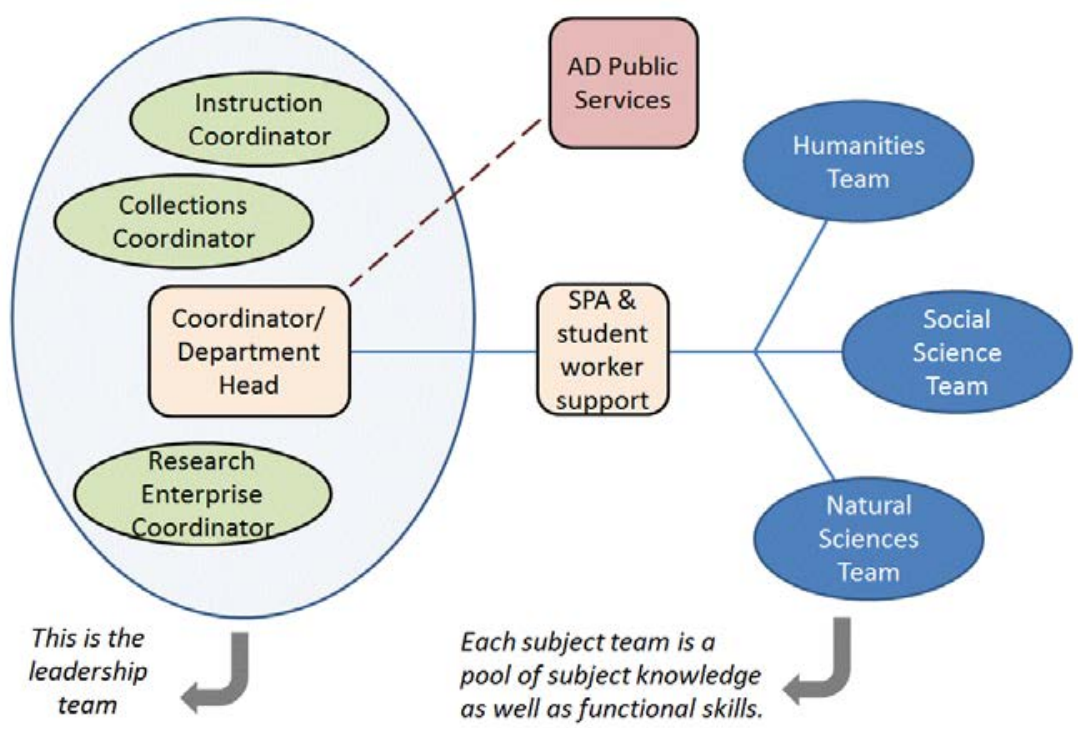

Figure 4. A Proposed Liaisons Department 
asking each liaison to consider de-duping print volumes after buying new e-journal backfiles, instead of automatically deciding to de-duplicate superseded holdings) could be changed to likewise reduce workload.

\section{Subject Team Model of a Liaisons Department}

The Liaisons Department is the home of the "full time" liaisons: those whose core responsibility is public service engagement with academic departments, learning communities, and research centers. The head of the Liaison Department reports to the AD for Public Services, reflecting the department's focus on public service (as we describe this model, we assume a Collections Department exists to allow the full-time liaisons to stop doing most of their present collections work.).

The Liaison Department has a leadership team consisting of the department head and functional coordinators. These coordinators provide expertise in core functional activities like instruction and research support, as well as assist the department head with goal-setting and annual evaluations. The functional activities represented by these coordinators become mainstreamed into the work of the department. The coordinators are also liaisons serving in the subject teams. The types of functional coordinators could change over time, reflecting evolving needs and priorities.

The liaisons are organized into subject teams characterized by collaboration and flexibility. Subject teams could include liaison partners (e.g., Jenny Dale and Kimberly Lutz covering English together) as well as LIS interns. Within each subject team, the liaisons pool their subject knowledge as well as functional expertise. Liaisons work together as needed to meet the library's engagement goals and the needs of academic departments (such teamwork is already happening in the library, if informally.). Teams work together to set teams goals and are held accountable for those goals. Different teams likely end up with different goals, depending on the nature of the academic departments being covered. For example, supporting research enterprise might be a more significant goal for the natural science and social science teams than the humanities team. Individuals still have goals established through their ALFAs.

Here are four possible examples of collaboration with a subject team:

- The library learns that several humanities departments are interested in learning more about the "digital humanities." The Humanities Team works together to sponsor a forum and discussion on the digital humanities for humanities professors.

- She Social Science Team develops a marketing campaign to promote open journal systems for the social science departments and research centers at UNCG.

- Faculty from several performing arts departments partner with several entrepreneurship professors on a grant project to study and promote arts entrepreneurship in Greensboro. The music, art, and business librarians join the project team to provide research skills and support concerning the arts industry (an example of collaboration across liaison subject teams).

- Four consecutive sections of NUR 210 (i.e., sections meeting back to back) desire a research workshop on a Monday in which the health science librarian will be out of town at a conference. That librarian works with two other members of the Natural Sciences Team to plan those workshops; the other two librarians lead the instruction on that Monday.

Each subject team has a coordinator who plans occasional subject team meetings and works with the department head on workflow and time load issues. This coordinator role could rotate among the liaisons in the team. Peer evaluations of teammates would be very important.

The subject knowledge, functional skill sets, and preferred liaison activities of the liaisons should be surveyed. Such a survey would help us define the skill sets available in each team and would help us determine what training or skills development would be most useful to pursue. 
While liaisons work together in subject teams, each liaison is still assigned target academic departments. Thus, the academic departments continue to have one identified liaison in order to facilitate communication and maintain a "human face" of the library.

There are still functional teams among the liaisons. For example, the specialists in instructional technology from each team could get together with the DE coordinator to work on projects that benefit all the liaisons. Such functional teams already exist here.

The SPA position assists the coordinator and the subject teams with their projects. Examples of possible work include:

- Leading library tours, teaching freshmen library instruction classes, and assisting with other teaching activities as needed;
- Helping develop instructional technology projects including LibGuides and video tutorials needed by the liaisons;

- Developing fliers, posters, brochures, and other publications needed by the liaisons;

- Assisting with promotional initiatives like faculty orientation, research fairs, etc.;

- Collecting liaison-related statistics and preparing reports;

- Scheduling departmental and subject team meetings and workshops; and

- Supervising and training a student worker.

These proposed Collection and Liaison Departments would not solve the work-load issues currently faced by the full time liaisons. Instead, prioritizing liaison responsibilities and campus units-and encouraging liaisons to say "no" more often based on those priorities-are

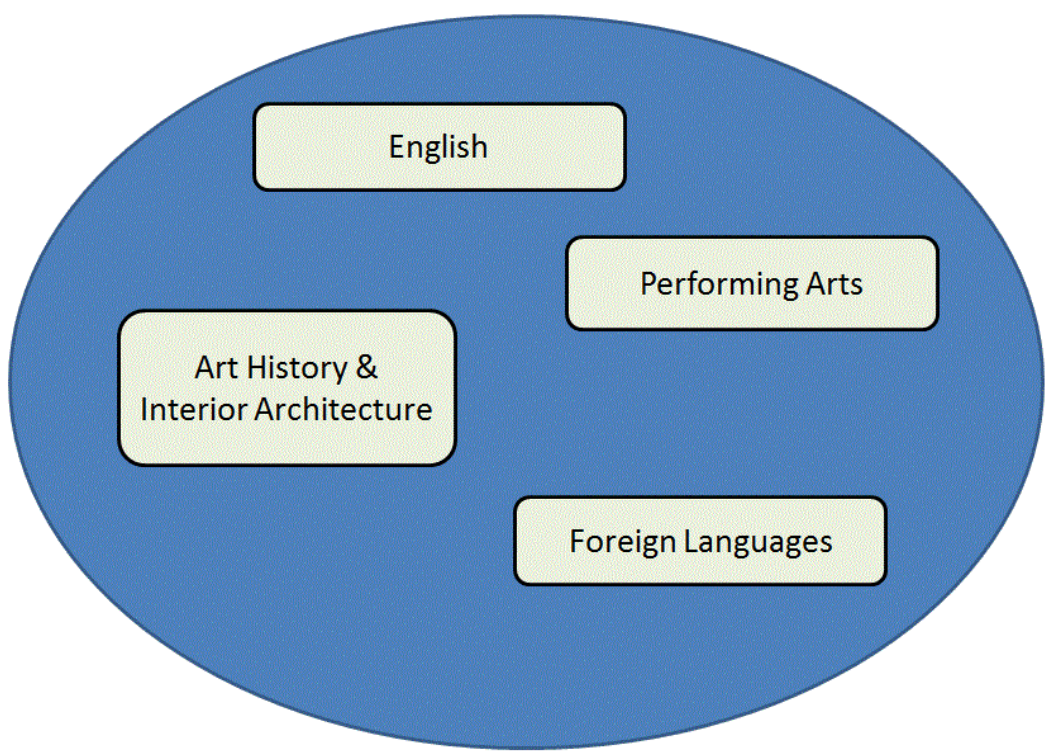

Figure 5. A Subject Team as a Pool of Subject Knowledge 


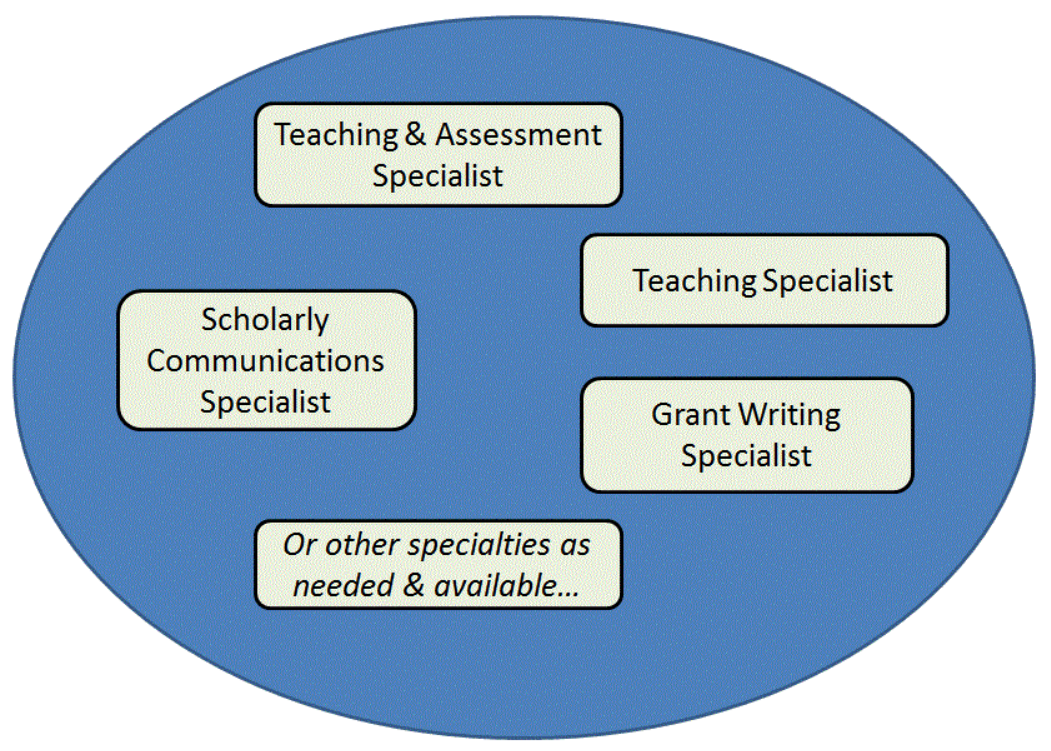

Figure 6. A Subject Team as a Pool of Functional Specialties

the actions that can really help with work load. Some campus units (departments, centers, learning communities, etc.) could get more attention and effort than others based upon their size, need for library resources and instruction, and importance to the university (what the Chancellor's "Decisions on Academic Program Review" calls "high priority programs"). Instead of a "one size fits all" approach, prioritizing would help the liaisons devote time and energy where they could have the greatest impact. The subject teams could discuss which academic department should get full attention and which should get minimal attention.

The "part-time liaisons" - those whose main responsibility is not liaison work (e.g., the current liaisons in ERIT) - would only liaise with academic departments for which significant public service engagement is not pursued. Those academic departments will only receive limited attention. If the number of full-time liaison positions increased, the library could consider providing full liaison support to more academic departments. Continued encouragement of more liaison partnerships could also help with workload issues. As with Jenny and Kimberly serving the English Department, the partners could divide the liaison responsibilities (e.g., public service vs. collections) or work out a more nuanced relationship. However, we don't think there would be enough partners available to cover all the current liaisons. Prioritizing which academic departments most need a liaison partner might be useful. We could survey all library workers on their subject or functional knowledge and learn of SPA or EPA workers with in-demand academic subject expertise. Then we could consider asking those folks to get involved in some aspect of liaison work.

If the library is able to create more full-time liaison positions, this liaison department could work with Administration on an intentional process to decide what subject and/or functional specialties are most needed. Campus and library strategic goals, public service statistics (or a lack thereof that might indicate the need for a liaison), growth trends in majors, etc., could all be considered in that decision.

According to our "Major Responsibilities of Liaisons," general reference service is not a part of liaison duties. Therefore, we have not addressed the staffing of the physical and online reference desk here. If we did create a Liaison Department from the existing Reference and Instructional Services department, we assume an interdepartmental team would staff reference services, with referrals made to liaisons as needed.

It might be useful at this point to review the "Strengths and Weaknesses of our Current Liaison Organizational Model" and consider how this Liaison Department model might preserve the 
current strengths while eliminating many of the weaknesses.

\section{Functional Team Model of an Academic Engagement Department}

This alternative model was inspired by the library at the University of Guelph. After losing 12 of its 34 positions in a crisis involving structural deficits, this library moved from a liaison service model to a team service model (details at http://www.lib. uoguelph.ca/about/components/documents/ organizational_renewal_2009.pdf).

In this functional team model, liaisons become functional specialists that serve any academic department, research center, etc., needing their specialized support. See Figure 7 for examples of possible functional teams.

The teams could change over time, reflecting the evolving priorities of the library and needs of the campus. For example, if the library makes data curation a top priority, a team could be formed to focus on that function (a team serving a lowerpriority function should probably be retired to compensate for the new team.).

In this model academic departments no longer have a decided library "face." Instead the academic departments are directed to the team coordinator appropriate to their functional needs. Some of the teams would probably have reason to collaborate (e.g., a First-Year Instruction Team and an Instructional Technology Team); other teams would have less reason to interact with others. While some librarians might serve on multiple teams, most librarians focus on one functional area.

The librarians would be able to leverage a core skill set, rather than be expected to have many skill sets. A strong emphasis on functional skills would have to be made in hiring decisions. Strong support of training opportunities to develop functional skills would be vital.

As with the subject team organizational model, a staff position would support the work of the functional teams.

\section{Appendixes}

Our task force report included three appendixes, not included here due to a lack of space:

Appendix 1: Recent Evolution of Collection Development at UNCG (a timeline).

Appendix 2: Resources on Prioritizing Liaison Responsibilities (examples from several universities).

Appendix 3: Most Relevant Articles from the Library Literature.

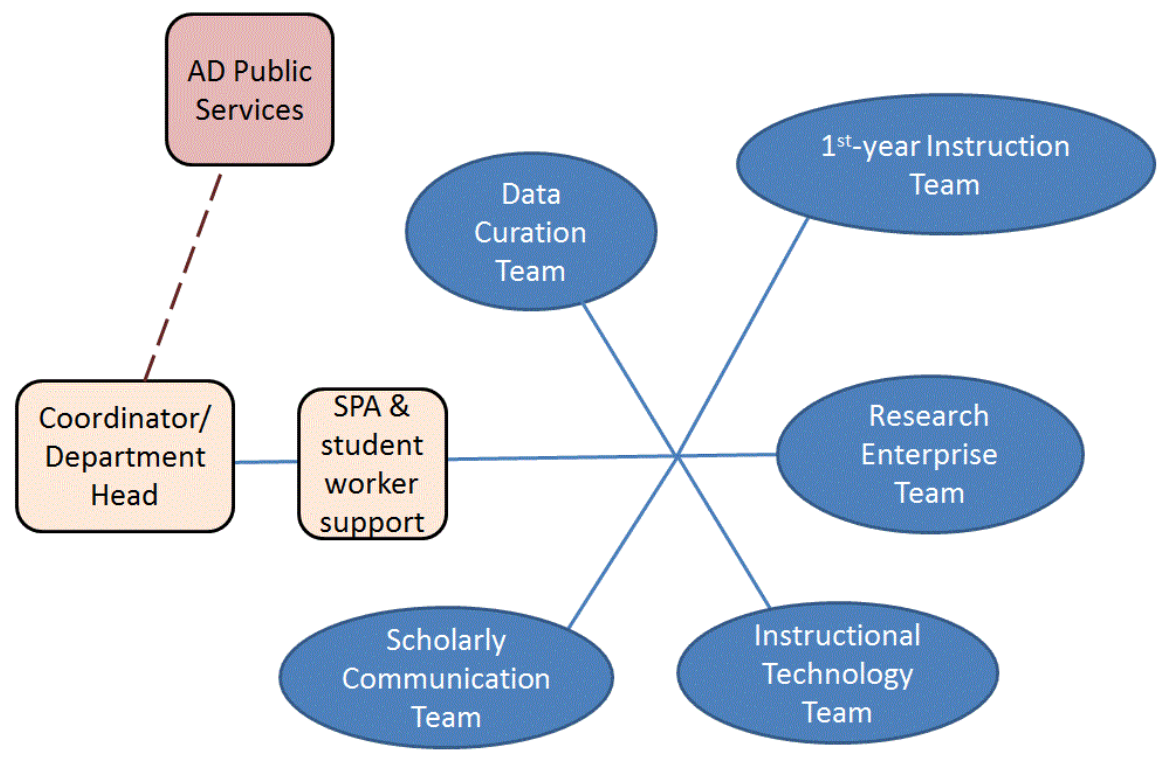

Figure 7. A Functional Team Model of an Academic Engagement Department 


\section{Epilogue}

As of late October 2012, task forces are being formed to implement a collections team among existing Acquisitions Department staff to provide staff support of collection development projects. Another implementation task force is forming to transform the exiting Reference Department into a Liaisons Department. 